\title{
Practices and Challenges of Guidance and Counseling Services in Secondary Schools

\author{
${ }^{a}$ Lecturer at Department of Psychology College of Education and Behavioral Science in Jimma University, Ethiopia
} \\ Aminu Jibril Arfasa ${ }^{a^{*}}$, Fisseha Mikrie Weldmeskel ${ }^{\text {b }}$ \\ ${ }^{b}$ Associate Professor, Department of Psychology, College of Education and Behavioral Science Jimma University, Ethiopia
}

\section{Abstract}

The purpose of this study was to examine the practices and challenges of guidance and counseling services in southwest Ethiopia secondary schools with the intention of understanding the state of secondary school guidance and counseling and forward improvement options to student service. The study employs a descriptive survey design that involves quantitative and qualitative research methods. The study participants were 392 students and 108 teachers who were selected from the secondary schools of southwest Ethiopia by systematic random sampling. Moreover, 8 counselors, 8 principals, and 8 educational bureau officers were selected by a means of availability sampling. The data for the study were collected by the administration of questionnaires and the use of oral interviews. The quantitative data were analyzed using the frequency of student visits to guidance and counseling office and mean perception score on practices of guidance and counseling. The qualitative data were analyzed using the thematic analysis method with a focus on the major challenges of guidance and counseling services in the sampled schools. The result of the study showed that the majority of secondary school students never visit guidance and counseling offices. The mean perception score of students and teachers towards the usefulness of the service was positive though the provision was either very much limited or most of the time unavailable. The services of guidance and counseling are also influenced by several challenges such as the lack of professionally trained counselors and the required facilities. The researchers conclude the implication of guidance and counseling service and the associated challenges to considerably influence secondary school student learning and personal wellbeing.
\end{abstract}

\section{Keywords:}

Guidance;

Counseling;

Practice;

Challenges. $\begin{array}{llll}\text { Article History: } & & \\ \text { Received: } & 19 & \text { November } & 2019 \\ \text { Accepted: } & 11 & \text { May } & 2020 \\ \text { Published: } & 01 & \text { June } & 2020\end{array}$

\section{1- Introduction}

School guidance and counseling service prepare students to assume increasing responsibility for their decisions and grow in their ability to understand and accept the results of their choices. There are effective implementations of guidance and counseling in educational system of developed nations. The service of guidance and counseling at schools provide a good opportunity for students to cope with the demands of learning and personal development [1]. When guidance and counseling services are not effective and face many challenges, students' adaptation becomes threatened leading to low academic performance, misbehaviour and dropout cases [2]. It is believed that when counselors have time, resources and the structure of a comprehensive program to work in, good things happen i.e. guidance and counseling interventions improve academic achievement, students take more demanding courses, develop and use career plans and learning and teaching institutions will have more positive climates [3]. In the words of Paolini (2019) [4] school counselors can utilize guidance and counseling techniques to enhance academic achievement and emotional wellness of all students, mitigate gun violence, use proactive strategies to combat bullying, as well as intervene on student substance abuse and its consequences on academic performance and student wellbeing.

\footnotetext{
*CONTACT: Aminujibril45@yahoo.com

DOI: http://dx.doi.org/10.28991/esj-2020-01222
}

(C) 2020 by the authors. Licensee ESJ, Italy. This is an open access article under the terms and conditions of the Creative Commons Attribution (CC-BY) license (https://creativecommons.org/licenses/by/4.0/). 
Currently, in the context of many African secondary schools, considerable progress has been made in setting up administrative structures for the provision of guidance and counseling services in educational institutions to enhance personal, educational and vocational development of the students [5]. Different researchers verify that school guidance and counseling officers play significant roles on students' aspirations, plans, enrolments, and financial aid knowledge. Guidance and Counseling is a process of helping students in making appropriate decisions and improving behavior. The purpose of guidance and counseling services is to impart specific skills and learning opportunities in a proactive and preventive manner which ensures that all students can achieve school success through academic, career, and personal/social development [6]. On the other hand, the effect of socioeconomic status on college enrolment of low-income students is largely explained by the lack of adequate counseling services [7]. By resolving physical, emotional, social and academic difficulties of the students and by helping them to understand their strengths and weaknesses; academic achievement can be improved and overall development can be enhanced [8]. When school counselors encourage acceptable behavior of the student and set workable plan to bring academic, social and emotional success not only supports the student-counselor relationship but also meets the goals of the comprehensive school guidance and counseling program [9].

Studies on the effects of school guidance and counseling have shown positive results on student's grades, reducing classroom disruptions, and enhancing teachers' abilities to manage classroom behavior effectively. High-quality school guidance and counseling services can also help to address students' mental health needs [10]. It is believed that when school counselors have time, resources, and furnished counseling room structure to work in; counseling intervention programs improve students' academic achievement [11]. In schools, students are constantly expected to do their best because of the belief that success in school is correlated with success in future life. With the world becoming more and more competitive, the quality of school performance has become a primary factor [12] is not only important to student but also to those around him/her [13]. The provision of guidance and counseling services by professionally trained counselors and/or other allied professionals is important undertaking. As Hregewoin and Yusuf (1998) [14] stated, adolescents in Ethiopian schools were suffering from withdrawal, dropout, economic and personal problems. This is partly due to the absence of professionally trained guidance and counseling personnel in the schools. Besides, lack of appropriate office and administration support, attitude of the society, school community and students to the services are other influential challenges. Similarly, as mentioned by Yirgalem (2013) [15] most school guidance and counselors reported to suffer from the shortage of private counseling room as well as most school principals and other officials wanted the Guidance and Counseling program to focus on education related issues like study skills, discipline and late coming. With the absence of clear roles and responsibilities, most visited guidance and counseling officers in the secondary schools were expected to serve as unit leaders.

Concerning the challenges faced in the provision of the service; different points can be raised. For instance, Poi Kee Low (2009) [16] looked at the challenges of counseling services in a school setting in four dimensions namely internal, external, systems and personal challenges. According to Ifelunni (2005) [17] in secondary school setting there are problems related with non-professionalization of counselors, low counselor/student ratio and the lack of recognition from the school administrators toward guidance and counseling services. In the words of Adane (2015) [2], lack of commitment and creativity by professionals to promote the profession in the school is mentioned as one of the major challenges to the service. In line with this almost twenty years ago Yusuf (1998) [14] has asserted that in schools some guidance and counseling personnel preparation and motivation to render the service to the needy students. Moreover, Yirgalem (2013) [15] points out that most of the secondary schools in Ethiopia do not have a separate office room for guidance and counseling services. In addition, this study mentioned as there are no clear roles and responsibilities of the school counselor with respect to rendering the services. As a result of this, most of the guidance and counseling personnel at the schools are expected to serve unit leaders. As Rashid et al. (2011) [18] state the role and responsibility of the counselor in educational institutions is much complex as compared to other organizations since there are legal, professional and organizational issues involved in the counseling process. Additionally, Adane (2015) [2] stated that absence of proper manual and job description about the services of guidance and counseling in schools and vague procedure to evaluate professionals at the end of the semester and academic year are also among the major challenges to continue in hindering effective guidance and counseling services in secondary schools.

Therefore, the current study intends to examine the practices and challenges of guidance and counseling services in south-West Ethiopia secondary schools more focusing on availabilities of guidance and counseling programs and professionals; roles and preparedness of school counselors, kinds of guidance and counseling service offered and their evaluation system; and the major challenges which are influencing the provision of guidance and counseling services for secondary school students. Thus, two important research questions were formulated to guide this study, namely (1) what are the practices of guidance and counseling in southwest Ethiopia secondary schools? And (2) what are the major challenges of guidance and counseling service in southwest Ethiopia secondary schools? 


\section{2- Research Methodology}

This study was conducted using descriptive research design that mixed up both quantitative and qualitative data collection and analysis. Eight secondary schools from southwest Ethiopia were identified as study places. A selfreported questionnaire was used to collect data on the current practice and challenges of guidance and counseling service at the secondary schools. Students and teachers at the schools filled out the questionnaire that involves leading questions such as the practices of guidance and counseling program and availability of professional; roles, evaluation systems and challenge facing guidance and counseling services. The questionnaire was designed in such a way that respondents check their opinion in a five point scale, which ranges from strongly agree (5 point) to strongly disagree (1 point).

Before the actual data collection for the study, the questionnaire was pilot tested on 30 students and 20 teachers of two secondary schools located in the same area. The schools in which the pilot test was conducted were excluded during the actual data collection time. The pilot test was helpful to check for the reliability of the questionnaire. Cronbach alpha coefficient was estimated to check the extent of internal consistency of the items in the questionnaire, and the result showed that reliability coefficient as 0.74 that is reasonably in the acceptable range. Moreover, the content validity of the questionnaire was reviewed by two counseling psychology lecturers of Jimma University as a result of which irrelevant items were discarded and some ambiguous items were modified.

In addition to experts' review and discussion, forward and backward translation of the questionnaire items was made to minimize meaning differences in the two local languages used during data collection (Afan Oromo \& Amharic). Hence, first the English version was translated to local languages with the help of both language experts. Then after the local languages versions of the questionnaire items were translated to English language so that valid instruments used for the collection of the required data for the study. Furthermore, to obtain additional information on the practices and the major challenges hindering the effective implementation of guidance and counseling services, interviews were conducted to collect data from key informants because they encourage exploration of the issues and allow pursuing information related to the practice and challenges of guidance and counseling services. Interviews were held only with the higher officials of the zonal/weredas educational bureau, guidance and counselors, and school principals. Following the completion of data collection, the coding was done for the completed questionnaire. Data analysis was made in line with answering the research questions raised. The data obtained from questionnaire was analyzed quantitatively using SPSS version 20 to report descriptive statistics such as frequency of student visit to counselor, percentage, mean scores and standard deviations. The qualitative data collected by interviews was also analyzed by thematic analysis approach. Qualitative data analysis was done for data collected from counselors, school principals and zonal/weredas educational bureau experts using the oral interview method.

\section{3- Results of the Study}

As outlined earlier in the abstract section, the main aim of this study was to examine the practices and the main challenges facing guidance and counseling services in southwest Ethiopia secondary schools. In this section data generated by questionnaire and interviews were presented in line with the research questions of the study.

Table 1. Students as study participants (number of schools $=8$ ).

\begin{tabular}{cccc}
\hline & & Frequency & Percentage \\
\hline \multirow{3}{*}{ Gender } & Male & 240 & 61.2 \\
& Female & 152 & 38.8 \\
\cline { 2 - 4 } & Total & $\mathbf{3 9 2}$ & $\mathbf{1 0 0 . 0}$ \\
\hline \multirow{4}{*}{ Age } & $13-15$ & 48 & 12.2 \\
& $16-18$ & 277 & 70.7 \\
& 19 and above & 67 & 17.1 \\
\cline { 2 - 4 } & Total & $\mathbf{3 9 2}$ & $\mathbf{1 0 0 . 0}$ \\
\hline \multirow{5}{*}{ Grade } & Grade 9 & 149 & 38.0 \\
& Grade10 & 46 & 11.7 \\
& Grade 11 & 123 & 31.4 \\
& Grade 12 & 74 & 18.9 \\
\cline { 2 - 4 } & Total & $\mathbf{3 9 2}$ & $\mathbf{1 0 0 . 0}$ \\
\hline
\end{tabular}

The above table1 shows the distribution of student's participants in gender, age, counseling usage and frequency of visit to the school counseling center. As shown in the above table, there were $240(61.2 \%)$ male and $152(38.8 \%)$ 
female participants. The majority of the secondary school student participants were aged between 16 and 18 years old. Therefore, as the above table shows it most participants were students who belong to the adolescent age group. Among total students participated in the study 149 (38\%) were in grade nine, $46(11.7 \%)$ grade ten, $123(31.4 \%)$ grade eleven 74 (18.9\%) grade twelve respectively.

Table 2. Students visit frequency to guidance and counseling office.

\begin{tabular}{cccc}
\hline & & Frequency & Percentage \\
\hline \multirow{2}{*}{$\begin{array}{c}\text { Visited G \& C office } \\
\text { Not visited G \&office }\end{array}$} & Seek & 155 & 39.5 \\
\cline { 2 - 4 } & Not seek & 237 & 60.5 \\
\hline \multirow{2}{*}{$\begin{array}{c}\text { Number of visits to G \& C office } \\
\text { in a year }\end{array}$} & Total & $\mathbf{3 9 2}$ & $\mathbf{1 0 0 . 0}$ \\
& None & 149 & 38.0 \\
& Tho times & 150 & 38.3 \\
& Three times & 92 & 17.1 \\
& Four times & 67 & 9.2 \\
\cline { 2 - 4 } & Five and more times & 36 & 5.1 \\
\hline
\end{tabular}

As Table 2 above depicts participant students of the study were also seen in terms of their usage of guidance and counseling services. The majority of the students who participated in the study, 237 (60.5\%), reported never seeking the school guidance and counseling services whereas $155(39.5 \%)$ of them were seeking guidance and counseling services. This implies that majority of students were not seeking guidance and counseling services. This may result from the lack of awareness to the benefits of guidance and counseling services or non-existence of the services in their schools. On the other hand, among the students who ever visited the school guidance and counseling center, the majority, $150(38.3 \%)$ visited the center only one time, $92(23.5 \%)$ twice and only $20(5.1 \%)$ had visited counseling center more than five times. From the students who visited the school guidance and counseling center, the majority were those who visited the center only one time. This shows that guidance and counseling practice in the schools is limited when seen from the number of students who have visited the centers.

Table 3. Teachers as study participants (number of schools $=8$ ).

\begin{tabular}{|c|c|c|c|}
\hline & & Frequency & Percent \\
\hline & Male & 76 & 70.4 \\
\hline \multirow[t]{5}{*}{ Gender } & Female & 32 & 29.6 \\
\hline & Total & 108 & 100.0 \\
\hline & $20-25$ & 21 & 19.4 \\
\hline & $26-29$ & 29 & 26.9 \\
\hline & $30-33$ & 38 & 35.2 \\
\hline \multirow[t]{6}{*}{ Age } & $34-37$ & 10 & 9.3 \\
\hline & $38-41$ & 5 & 4.6 \\
\hline & 42 and above & 5 & 4.6 \\
\hline & Total & 108 & 100.0 \\
\hline & Diploma & 4 & 3.7 \\
\hline & First degree & 88 & 81.5 \\
\hline \multirow[t]{5}{*}{ Educational level } & Master's degree & 15 & 13.9 \\
\hline & Other & 1 & .9 \\
\hline & Total & 108 & 100.0 \\
\hline & Language & 17 & 15.7 \\
\hline & Sciences & 58 & 53.7 \\
\hline \multirow[t]{3}{*}{ Subject specialty of the teacher } & Social & 32 & 29.6 \\
\hline & Others & 1 & .9 \\
\hline & Total & 108 & 100.0 \\
\hline
\end{tabular}


Table 3 above shows the data on teacher respondents in the study. The total number of teachers who have participated in the study was 108 , of which $76(70.4 \%)$ of them were males while the remaining $32(29.6 \%)$ were females. The majority of teachers involved in the study, 29 (35\%) were between the age range of 30-33, while few $5(4.6 \%)$ teachers were above the age of 42 . Regarding to education level of teachers, majority of them $88(81.5 \%)$ were trained at first degree level, $15(13.9 \%)$ were master degree holders while $4(3.7 \%)$ were diploma holders. Among the total teacher participants 58(53.7\%) specialized in the natural science fields, and $32(29.6 \%)$ of them educational preparation was in the social science fields while $17(15.7 \%)$ of them had their trainings in the various language studies including English as a foreign language fields.

Table 4. Practices of guidance and counseling services.

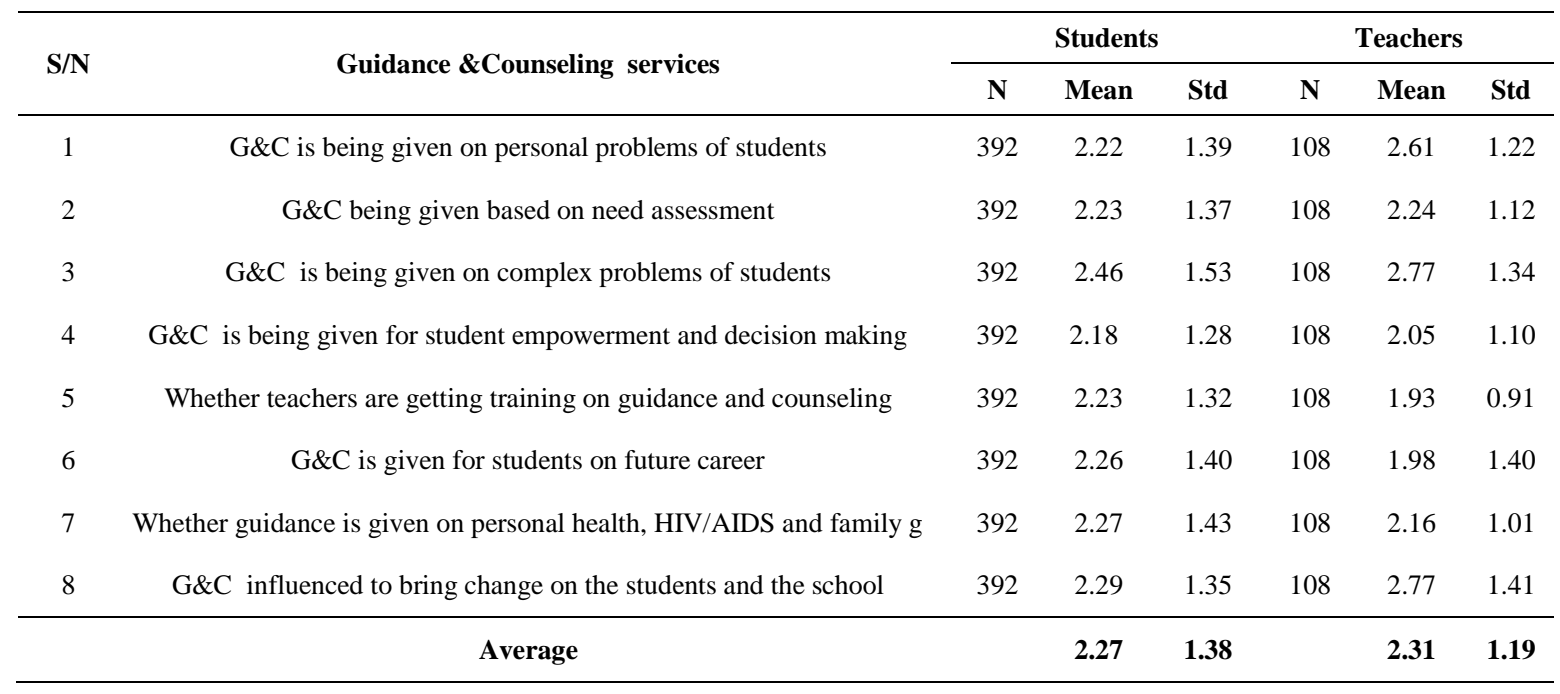

Table 4 above shows practice of guidance and counseling mean perception scores of students and teachers in their schools. The mean scores show that the perception of the students and teachers towards the eight key practices of guidance and counseling was found to be low, which means the students average response to the key practices of guidance and counseling services at the schools was 2.27 with a standard deviation of 1.38 . In the same way, the teachers' average perception to the key practices remains to be 2.31 with a standard deviation of 1.19 . These results in general approximate a response of disagreement ( $=2$ points $)$ than either agree $(=4$ points $)$ and strongly agree $(=5$ points), which means that in the eight schools sampled, almost all students $(n=392)$ and teachers $(n=108)$ witnessed the non-availability of the eight key practices with respect to school guidance and counseling services. Further examination of the data in the table reveals that the practice of arranging guidance and counseling service for students' personal problems received a mean of 2.22 by student respondents and mean of 2.61 by teacher respondents. Regarding whether guidance and counseling services working based on need assessment the mean scores of both students and teachers reveled below average. This was observed in the students mean score of 2.23 while the mean score of teacher respondents was 2.24. These average scores imply that the services of guidance and counseling at the sampled secondary schools were not based on needs assessment.

The mean score of students and teachers toward guidance and counseling services aimed at student empowerment and decision making was also less than average. The mean score of students was $(\mathrm{M}=2.18)$ with standard division $(\mathrm{SD}=1.28)$ and the mean score of teachers was $(\mathrm{M}=2.05)$ with standard division $(\mathrm{SD}=1.10)$. On the other hand, the mean score of students toward guidance and counseling services given on students future career has received a mean score of $(\mathrm{M}=2.26)$ with standard division $(\mathrm{SD}=1.40)$ and mean score of teachers was $(\mathrm{M}=1.98)$ with standard division $(\mathrm{SD}=1.40)$. These results revealed that most of guidance and counseling centers in the study area were not actively working on student's empowerments and decision making as well as on career developments. Concerning whether secondary school guidance and counseling working on the issues of HIV/AIDs and other related issues students mean score was $(\mathrm{M}=2.27)$ with standard division $(\mathrm{SD}=1.43)$ and the teachers mean score was $(\mathrm{M}=2.16)$ with standard division $(\mathrm{SD}=1.01)$. This implies that guidance and counseling in the study area also not effectively working on cases of HIV/AIDS and related issues. Also for the questions whether guidance and counseling services in the study area influence students to bring change, the mean score of students was $(\mathrm{M}=2.29)$ with standard division of $(\mathrm{SD}=1.35)$ and the mean score of teachers was $(\mathrm{M}=2.77)$ with standard division $(\mathrm{SD}=1.41)$. From these results it can be concluded that the school guidance and counseling was not effectively functioning and not influencing students to bring changes on their academic success and behavior adjustment. 
Table 5. Challenges of guidance and counseling services.

\begin{tabular}{lccccccc}
\hline \multirow{2}{*}{ S/N } & Challenges of Guidance \& counseling & \multicolumn{3}{c}{ Students } & \multicolumn{3}{c}{ Teachers } \\
\cline { 3 - 8 } & & $\mathbf{N}$ & Mean & Std & N & Mean & Std \\
\hline 1 & Lack of good place and equipment & 392 & 3.50 & 1.37 & 108 & 3.77 & 1.44 \\
2 & Lack of qualified counselor & 392 & 3.21 & 1.41 & 108 & 3.47 & 0.54 \\
3 & Limitation of place for group counseling & 392 & 3.18 & 1.33 & 108 & 3.33 & 1.39 \\
4 & Absent o clear direction from MOE & 392 & 3.43 & 1.34 & 108 & 3.76 & 1.32 \\
5 & students lack interest & 392 & 3.32 & 1.38 & 108 & 3.32 & 1.44 \\
6 & trust on part of teachers & 392 & 3.26 & 1.35 & 108 & 1.91 & 0.94 \\
7 & trust on part of principals & 392 & 3.16 & 1.30 & 108 & 2.10 & 1.17 \\
8 & Lack of good place and equipment & 392 & 3.50 & 1.37 & 108 & 3.77 & 1.44 \\
9 & students say that consoling is useless & 392 & 2.86 & 1.27 & 108 & 2.79 & 1.42 \\
\hline & Total & & $\mathbf{3 . 2 7}$ & $\mathbf{1 . 3 5}$ & & $\mathbf{3 . 0 6}$ & $\mathbf{1 . 2 3}$ \\
\hline
\end{tabular}

As table 5 above showed there seems a presence of agreement by both student and teacher respondents towards the non-existent of a separate office for the provision of guidance and counseling services at the secondary schools. This can be depicted from the average mean score of students, $(M=3.50)$ and that of teachers, $(M=3.77)$ respectively. Moreover, the average responses from the study participants towards the listed impediments of guidance and counseling services at the schools were found to be more than average agreement. That means, the schools are indeed suffering from the lack of counseling office, professionally trained counselors, students' lack of interest in the services, absence of clear direction on the provision of guidance and counseling services, and limitation of space to conduct group counseling, and lack of direction and standard manuals for the practice.

The interview conducted with school principals and school counselors also supported the above mentioned challenges such as lack of separate guidance and counseling room with necessary equipment, lack of cooperation from teachers and lack of clear rule and supervision mechanisms from the Ministry of education in general and absence of guideline and support from zonal and wereda educational departments, and the school community. Moreover, it is well understood that office of guidance and counseling is resource demanding. In the present study many of the secondary schools were challenged because of lack of resources that the office demands including enough number of human resources that address the number of students, best equipped office for service, entertainments for psychological relief, computer and internet service, reading books, manuals and others necessary office materials for the effective implementation of guidance and counseling. The qualitative study also revealed that the offices of guidance and counseling in the schools have very few materials that can help for the effective implementation of guidance and counseling. Almost all of the offices in the sampled schools do not have reference books for counselors, internet service, and different reading materials.

The job descriptions for secondary school guidance and counseling officers was non-existent as the interviews conducted with school counselors and principals revealed. As learnt from the interviews, job standards and performance appraisal criteria for the counselor are not found in the schools. Moreover, the interview results revealed the absence of manuals and other related materials on how to conduct guidance and counseling in schools and the strategies to be used in improving the professional growth of guidance and counseling officers.

\section{5- Discussion}

The main purpose of this study was to examine the practices and challenges of guidance and counseling services in southwest Ethiopia secondary schools. Thus, the study was guided by two main research questions, namely (1) what are the practices of guidance and counseling services in south west Ethiopia secondary schools? And (2) what are the major challenges of guidance and counseling service in southwest Ethiopia secondary schools?

Based on the result of the study, the mean scores of teacher and student respondents towards the practices of guidance and counseling services was found to be near to disagreement, which means that the eight key practices of guidance and counseling service indicated in the questionnaire were not practiced well in the participated schools. More specifically, guidance and counseling programs did not operate based on need assessment and the provision of the services on personal problems, encouraging empowerment and decision making, future career plans, on personal health, HIV/AIDS and family guidance and to bring change in student behavior was minimum and not to the expected level. This result is similar with the study findings by Yirgalem (2013) [15] that reported poor practices of guidance and counseling services in the secondary schools of East Harerg zone in Oromia. Oye et al. (2012) [19] mentioned the essence of incorporating guidance and counseling into the school system was to eliminate overwhelming ignorance of many young people on their choices of career prospects and personality maladjustment. Similarly, Lazarus and 
Lazarus and Ihuoma (2011) [20]) reveled that schools counselors assist learners in guiding decision-making and opportunities for students future career plans. According to Gysbers et al. (2011) [21] comprehensive guidance and counseling program addresses the needs of students by facilitating for their academic success, career development, and personal/social development, helping create positive and safe learning climates in schools, as well as helping students feel connected to school and to at least one caring adult. Mwangi and Otanga's (2015) [22] finding also indicate that majority of young persons to have a positive perception about guidance and counseling services in school enviropments. This may be attributed to the students' evaluation and appreciation of the guidance and counseling services offered in their institution and the ability of the counselors to discharge these services. Momanyi (2015) [23] assert that positive perception of students about guidance and counseling service is a result of access to information about the program and the positive meaning they attach. Ndhlovu (2015) [24] postulated that counselors may provide guidance and counseling services in three broad ways: through the directive, nondirective and eclectic methods.

With respect to the main challenges of guidance and counseling services at the secondary schools, both the student and teacher respondents almost agreed on the presence of all the mentioned challenges in the study to be potential barriers of the services. The challenges recognized by the respondents were found to be the lack of separate counseling office and necessary equipment, absence of professionally trained guidance and counseling personnel, clear rules and guidelines and the lack of support from stakeholders. Similarly interview held with the school principals and counselors also showed the same ideas with the mentioned challenges to be present in the secondary schools. The study by Yirgalem (2013) [15] in the eastern Hararghe zone of Oromia also revealed similar results, in that most school guidance and counseling officers did not have private counseling rooms. In a similar study conducted by Kelkay (2019) [25] among Gonder town secondary school students (Ethiopia) the major challenges to the services of school guidance and counseling were found to be the lack of constant support from school administrators and other teachers, shortage of required facilities, teaching overload of counselors, unavailability of professionally trained guidance and counseling officers in the schools, lack of training for the service providers, poor awareness on the benefits of guidance and counseling service from educational personnel and authorities including students unwilling to discuss their adjustment problems. Surprisingly, almost more than twenty years ago Yusuf [14] also mentioned the lack of appropriate office and stakeholders support; attitude of the society; school community and students misunderstanding to the services of guidance and counseling as the major challenges to practices of guidance and counseling in the secondary schools of Ethiopia. As Egbo's (2015) [26] study (2015) reveal it, school guidance and counseling officers perceive negative attitude of the public and uncooperative attitude of principals and teachers as the major challenges to counseling service at secondary schools of Nigeria. Mushaandja et al. (2013) [27] noted that school counselors were not given adequate support by the school administrators and teachers. They attributed this to the lack of sufficient information in counseling on the part of the counselor and school administrators. A study by Nyamwange et al. [28] also revealed that support given to counselors by their school administrators and department of education at the various levels is very minimal, as a result of which the service of guidance and counseling at secondary schools is often jeopardized. This state of affairs is unfortunate because it is hard for guidance and counseling officers to render the required services without support of the school administration and other responsible personnel in the education system.

Furthermore, the absence of written job description of guidance and counseling officers, documents stating the roles and responsibilities of school counselors and the lack of performance evaluation found to be big challenges to the effective practice of school guidance and counseling. This finding is similar with Adane (2015) [2] finding on the absence of proper manual and job description on the e services of guidance and counseling in schools and also the vagueness of the procedures to evaluate the counseling professionals at the end of the semester and year as big challenges to the effective practice of school guidance and counseling. Also absent of professional supervision is affecting guidance and counseling I the study areas. Professional conferences also provide school counselors with professional development opportunities that may be more accessible and efficient than taking a graduate course in supervision. Professional conferences may even be more likely to provide school counselors with supervision training sessions that are geared more towards the school setting [1].

\section{6- Conclusion}

In the case of southwest Ethiopia, among selected 18 secondary schools only 8 of the secondary schools have guidance and counseling centers. This may be indication to the underestimation of school guidance and counseling and its benefits in the context of the study that is in contrast to the present attention it received in many school systems. Among secondary schools having guidance and counseling center, only four secondary schools have professionally trained personnel while in the remaining four schools guidance and counseling officers were from different fields of study. This implies that most of the secondary schools which are located in southwest of Ethiopia a were not providing effective guidance and counseling services for students due to lack of centers and nonexistence of professional counselors, while several universities in the nation are preparing psychology graduates who can be 
deployed to the secondary schools to provide proper services in guidance and counseling.

While most of the secondary schools guidance and counseling officers were non-professionals; they are not actively working due to non-professionalism and lack of the proper knowledge, skills, supports and training that make their practice effective. Thus non-professionalism and lack of training for guidance and counseling personnel leads to the limited practices southwest Ethiopia secondary schools.

Though students and teachers responses towards the activities of guidance and counseling services are positive, the provisions of the services in those schools were highly limited or unavailable. The mean scores of students and teachers on types of guidance and counseling services were too small. The provision of guidance and counseling services on personal problems, encouraging empowerment and decision making, future career plans, on personal health, HIV/AIDS and family guidance and to bring behavioural change on the students and the school were insignificant. Thus, the students in those schools were in a disadvantage as they were not benefiting the services of guidance and counseling for both personal and academic related problems they encounter.

The mean scores of students and teachers towards of challenges and limitations of guidance and counseling services were high values. This implies that most of the counseling centers in southwest Ethiopia secondary schools were challenged by the lack of separate office and the necessary equipment, professionally trained personnel, clear rules and guide, and lack of support from stalk holders.

Job description manuals for guidance and counseling personnel were also non-existent in the sampled secondary schools. As a result of which the personnel were not able to accomplish their duties properly. Perhaps, the personnel are also discouraged as they have no job performance evaluation results on semester and yearly bases. In addition, the arrangement of separate counseling office, presence of job description and service manual, and other required schemes including job performance appraisal of the guidance and counseling personnel may bring improvements in the services of student counseling at schools. In the present study, the researchers have found out that guidance and counseling service provision in the study context was insignificant due to most of the secondary schools lack professional counselors and counseling centers, necessary equipment, clear rules and regulation. Most of the school guidance and counseling services are run by non-professionals who never received the required training in the profession. Thus, giving attention to the preparation of professional counselors and upgrading the knowledge and skills of those already providing the service is believed to be salient to improve the situation of guidance and counseling in secondary schools.

\section{7- Conflict of Interest}

The author declares that there is no conflict of interests regarding the publication of this manuscript. In addition, the ethical issues, including plagiarism, informed consent, misconduct, data fabrication and/or falsification, double publication and/or submission, and redundancies have been completely observed by the authors.

\section{8- Ethical Approval}

Participants gave their written consent to use their anonymous data for statistical purposes. All of them were over 18 years old and voluntarily collaborated without receiving any financial compensation.

\section{9- References}

[1] Neyland-Brown, Leslie, John M. Laux, Jennifer L. Reynolds, Kelly Kozlowski, and Nick J. Piazza. "An Exploration of Supervision Training Opportunities for School Counselors." Journal of School Counseling 17, no. 1 (2019).

[2] Adane, W., J . "The Need, Practice and Challenges of Guidance and Counseling Services in Selected Sidama Zone Secondary Schools of SNNPRS Ethiopia”: The International Journal of Humanities \& Social Studies 3 no 6 (June 2015).

[3] Scholl, Mark B., A. Scott McGowan, and James T. Hansen. "Introduction to humanistic perspectives on contemporary counseling issues." In Humanistic perspectives on contemporary counseling issues. Routledge, (2013): 21-32.

[4] Paolini, Allison C. "School Counselors Promoting College and Career Readiness for High School Students." Journal of School Counseling 17, no. 2 (2019).

[5] Boitt, Monicah Lydia. "Evaluation of the Challenges in the Implementation of the Guidance and Counselling Programme in Baringo County Secondary Schools, Kenya." Journal of Education and Practice 7, no. 30 (2016): 27-34.

[6] American School Counselors Association. “The Role of the professional school Counselor” Alexandria, VA: (1997).

[7] King, Jacqueline E. "The Decision To Go to College: Attitudes and Experiences Associated with College Attendance Among Low-Income Students." New York: The College Board. (1996).

[8] Hregewoin, C. \& Yusuf, O.A. "Facilitating assertiveness among female college students” Addis Ababa, by EMPDA. (1994). 
[9] Buchanan, Deborah K., Blair Sumner Mynatt, and Marianne Woodside. "Novice school counselors' experience in classroom management." The Journal of Counselor Preparation and Supervision 9, no. 1 (2017): 2. doi:10.7729/91.1146.

[10] United States. Department of Education. Office of the Under Secretary, United States. Office of Elementary, and Secondary Education. "No Child Left Behind: A Desktop Reference", (2002).

[11] Day, S. X., "Theory and Design in Counseling and Psychotherapy”. Boston, NY: Houghton Mifflin Company, (2004).

[12] Nuthana, P. G. " Gender Analysis of Academic Achievement among High School Students." PhD diss., UAS, Dharwad, (2007).

[13] Agi, Comfort W. "Evaluation of the Status of Guidance Services in Secondary Schools in Rivers State, Nigeria." Journal of Education and Practice 4, no. 23 (2013): 78-84.

[14] Abdi, Y. "Gender sensitive counseling psychology: A handbook for Ethiopian high school counselor." Addis Ababa (1998).

[15] Alemu, Yirgalem. "Assessment of the provisions of guidance and counseling services in secondary schools of East Harerge Zone and Hareri Region, Ethiopia." Middle Eastern \& African Journal of Educational Research 2, no. 6 (2013): 28-37.

[16] Low, Poi Kee. "Considering the Challenges of Counselling Practice in Schools." International Journal for the Advancement of Counselling 31, no. 2 (March 17, 2009): 71-79. doi:10.1007/s10447-009-9069-1.

[17] Ifelunni, I. "The missing links in Nigerian Education system." In Keynote address presented at a conference on the state and future of Education in Nigeria. FCE (Technical) Asaba, (June 2005): 13-17.

[18] Mehmood, Rashid, Mubashir Hussain, and Ali Iftikhar Chaudhry. "Student counseling: adding value to educational institution." Journal of Education and Vocational Research 2, no. 3 (September 2011): 116-119.

[19] D., Oye N., Obi M. C., Mohd T. N., and Bernice A. "Guidance and Counseling in Nigerian Secondary Schools: The Role of ICT." International Journal of Modern Education and Computer Science 4, no. 8 (August 14, 2012): 26-33. doi:10.5815/ijmecs.2012.08.04.

[20] Lazarus, Kelechi U., and Chinwe Ihuoma. "The role of guidance counsellors in the career development of adolescents and young adults with special needs." British Journal of Arts and Social Sciences 2, no. 1 (2011): 51-62.

[21] Gysbers, N. C., J. B. Stanley, L. Kosteck-Bunch, C. S. Magnuson, and M. F. Starr. "Missouri Comprehensive Guidance and Counseling Program": A Manual for Program Development, Implementation, Evaluation and Enhancement. 2011. Available online: http://docplayer.net/7970086-Missouri-comprehensive-guidance-and-counseling-program.html (accessed on 21 December 2019).

[22] Mwangi, Jayne, and Habil Otanga. "Students' perception and Attitude towards the Role of Guidance and Counselling Services in Teachers Colleges in Kenya." International Journal of Contemporary Applied Sciences 2, no. 8 (August 2015).

[23] Momanyi, Lilian. "Perceptions of Teachers and Students towards Guidance and Counselling Services in Public Secondary Schools in Ongata Rongai and Ngong Zones of Kajiado North District, Kajiado County-Kenya." PhD diss., (2015).

[24] Ndhlovu, D. "Theory and Practice of Guidance and Counseling": Lusaka, UNZA Press. (2015).

[25] Kelkay, Asrat Dagnew. "Practice and Challenges in Provision of Guidance and Counselling Services in Secondary Schools of South Gondar, Ethiopia." Global Journal of Guidance and Counseling in Schools: Current Perspectives 9, no. 1 (April 30, 2019): 1-13. doi:10.18844/gjgc.v9i1.3859.

[26] Egbo, A. C. "The Challenges of Guidance and Counselling Practices as perceived by Secondary School Counsellors in Enugu State Nigeria." International Journal of Education and Research 3, no. 5 (May 2015): 375-384.

[27] Mushaandja, John. "Major Challenges Facing Teacher Counselors in Schools in Namibia.” Education Journal 2, no. 3 (2013): 77. doi:10.11648/j.edu.20130203.13.

[28] Nyamwaka, E. O., PAUL C. Ondima, C. Nyamwange, S. A. M. S. O. N. Ombaba, and EVANGELINE K. Magaki. "Assessment of implementation levels of Guidance and counselling programme in Kenyan secondary schools: A case of Sotik district, Bomet County, Kenya." Journal of Education and Practice 4, no. 3 (2013): 178-186. 